\title{
АНАЛІЗ СИСТЕМИ СТРАТЕГІЧНОГО УПРАВЛІННЯ ОПЕРАТОРА ГАЗОТРАНСПОРТНОЇ СИСТЕМИ УКРАЇНИ ТА ВИЗНАЧЕННЯ ПЕРСПЕКТИВ ЙОГО РОЗВИТКУ
}

\author{
Луиький національний технічний університет
}

\begin{abstract}
В нинішніх мінливих умовах господарювання, ряду підприємств не легко зайняти свою нішу у сфері робіт, товарів чи послуг. Ще складнішою задачею є втримати свої позиції на ринку, зміцнити їх, чи показати довгострокову позитивну тенденцію зростання. Зміни зовнішнього середовища, політична дестабілізація, слабка економіка, світова пандемія, не визначений рівень соціального захисту населення це ключові фактори, які впливають на розвиток підприємства нині. Для зменшення ризиків і загроз зовнішнього середовища, а навпаки, використання його можливостей, для розуміння, як реагувати на непередбачувані економічні фактори, як ефективно використовувати свій потенціал, як захистити своє підприємство у конкурентній боротьбі, потрібна система організаційно-економічних заходів для досягнення довгострокових цілей, або стратегія.

3 метою зменшення ризиків та загроз зовнішнього середовища, використання його можливостей, ефективного використання свого внутрішнього потенціалу, кожному підприємству необхідний виважений план стратегічного розвитку, сформована системи стратегічного управління для досягнення цілей організації. У статті висвітлено теоретичні засади стратегічного управління підприємством. Проведене детальне аналітичне дослідження ринку природного газу в Україні, що дозволило встановити нинішні тенденції споживання природного газу в Україні. Здійснено аналіз системи стратегічного управління оператора газотранспортної системи України, зокрема систематизовано цілі діючої стратегії та розглянуто напрямки і заходи, щодо їх впровадження.

В статті сформовано пропозиції, щодо удосконалення плану стратегічного розвитку аналізованого підприємства, зважаючи на сучасні умови управлінської діяльності. Розглянуто можливість розробки Олеської та Юзівської газоносних сховищ, видобутку та транспортування сланцевого газу, що може стати перспективною для ГТС України. Проведене прогнозування та аналіз орієнтовної вартості робіт, щодо видобутку скрапленого газу.

Ключові слова: стратегічне управління, план розвитку, газотранспортна система, природний газ, сланцевий газ, альтернативи розвитку.
\end{abstract}

\section{ANALYSIS OF THE STRATEGIC MANAGEMENT OF THE GAS TRANSMISSION SYSTEM OPERATOR OF UKRAINE AND DETERMINATION OF ITS DEVELOPMENT PROSPECTS}

\section{Lutsk National Technical University}

In the current changing business environment, a number of companies are not easy to occupy their niche in the field of works, goods or services. An even more difficult task is to maintain their position in the market, strengthen them, or show a long-term positive growth trend. Changes in the external environment, political destabilization, weak economy, global pandemic, undefined level of social protection - these are the key factors that affect the development of the enterprise today. To reduce the risks and threats of the external environment, and vice versa, to use its opportunities, to understand how to respond to unpredictable economic factors, how to effectively use its potential, how to protect your business in competition, you need a system of organizational and economic measures to achieve long-term goals. or strategy.

In order to reduce the risks and threats of the external environment, use its capabilities, effective use of its internal potential, each company needs a balanced plan of strategic development, formed a system of strategic management to achieve the goals of the organization. The article highlights the theoretical foundations of strategic management of the enterprise. A detailed analytical study of the natural gas market in Ukraine was conducted, which allowed to establish the current trends in natural gas consumption in Ukraine. The analysis of the strategic 
management system of the gas transmission system operator of Ukraine is carried out, in particular the goals of the current strategy are systematized and the directions and measures for their implementation are considered.

The article contains proposals for improving the strategic development plan of the analyzed enterprise, taking into account the current conditions of management. The possibility of developing Oleska and Yuzivska gas storage facilities, production and transportation of shale gas, which may become promising for the GTS of Ukraine, is considered. The forecasting and analysis of the estimated cost of works on liquefied gas production was carried out.

Key words: strategic management, development plan, gas transmission system, natural gas, shale gas, development alternatives.

Постановка проблеми у загальному вигляді i ïi зв'язок 3 важливими науковими та практичними завданнями. В період світової економічної нестабільності, ряду підприємств не легко зайняти свою нішу у сфері робіт, товарів чи послуг. Ще складнішою задачею є втримати свої позиції на ринку, зміцнити їх, чи показати довгострокову позитивну тенденцію зростання. Для зменшення ризиків і загроз зовнішнього середовища та навпаки, використання його можливостей, для розуміння, як реагувати на непередбачувані економічні фактори, як ефективно використовувати свій потенціал, як захистити своє підприємство у конкурентній боротьбі, потрібна система організаційно-економічних заходів для досягнення довгострокових цілей. Ефективність стратегічного управління в діяльності підприємства чи організації являється ключовою умовою його перспективи розвитку.

Аналіз останніх досліджень, у яких започатковано вирішення проблеми. Питання, щодо формування системи стратегічного управління було грунтовно досліджено в працях таких вчених-економістів, як 3. С. Шерньова, Л. М. Романюк, О. П. Пащенко, I. Ансоф, І. В. Давиденко, В. А. Белошапка. Проте, глибокий аналіз системи стратегічного управління підприємства, пошук новаторських, інноваційних методів вдосконалення стратегічних планів, дасть можливість впровадження дієвих заходів для розвитку організації.

Цілі статті. Мета даної статті полягає у дослідженні ефективності системи стратегічного управління оператора газотранспортної системи України 3 метою формування пропозицій, щодо ії вдосконалення, з врахуванням інноваційного аспекту.

Виклад основного матеріалу з повним обгрунтуванням отриманих наукових результатів. Розвиток будь-якого підприємства залежить від багатьох факторів і чинників, які на пряму чи опосередковано на це впливають. В період становлення ринкової економіки в Україні, що заснована на принципах вільного підприємництва, основним регулятором економічних відносин стає сам ринок і споживач. Зміни зовнішнього середовища, політична дестабілізація, слабка економіка, не визначений рівень соціального захисту населення - це ключові фактори, які впливають на розвиток підприємства.

Комплекс цілей організації, що плануються реалізовуватись для досягнення запланованих результатів і передбачають у собі вирішення наявних проблем, створення умов розвитку чи освоєння нового напрямку діяльності на основі реалізації потенціалу підприємства та ключових факторів успіху являється його стратегією. Для розвитку підприємства і його процвітання самої стратегії, як ідеї не достатньо. Формування і реалізації чіткого комплексу дій і заходів, спрямованих на досягнення цілей розвитку, аргументовує необхідність системи стратегічного управління.

Стратегічне управління - це процес, за допомогою якого менеджери здійснюють довгострокове керування організацією, визначають специфічні цілі діяльності, розробляють стратегії для досягнення цих цілей, враховуючи всі релевантні (найістотніші) зовнішні умови, а також забезпечують виконання розроблених відповідних планів, які постійно розвиваються і змінюються [1, с. 16]. 
Основні переваги, які може забезпечити стратегія в діяльності підприємства: зменшення впливу негативних наслідків майбутніх періодів зовнішнього і внутрішнього середовища; алгоритм розвитку, що дає чіткі уявлення перспективних дій; можливість ефективного розподілу коштів; можливість зробити організацію, гнучкою, пристосованою до змін; можливість поетапного створення матеріально - технічної бази; проведення постійного аналізу, моніторингу підприємства.

Для постійного розвитку і процвітання кожній структурі необхідно вибудувати певний алгоритм стратегічних дій, на основі стратегічних цілей, що сприятиме адаптивності до змін, що постійно відбуваються, зменшуючи ризики, що впливають на розвиток організації. Разом з тим, дана система планів, дій дає можливість ефективно реалізовувати і розвивати конкурентні переваги організації та іï фактори успіху.

Чіткий, послідовний взаємозв'язок дає можливість обгрунтування напрямків діяльності підприємства і послідовності дій при реалізації стратегічного управління. До основних етапів стратегічного управління відносяться:

- $\quad$ формування місії (основного завдання), постановка цілей;

- $\quad$ аналіз зовнішнього середовища (макросередовище, мікросередовище);

- $\quad$ аналіз підприємства (управлінське обстеження);

- розробка стратегії та вибір 3 можливих стратегічних альтернатив

розвитку;

- реалізація стратегіі;

- $\quad$ контроль за виконанням стратегії.

Сформовані етапи не можуть бути єдиним підходом у процесі стратегічного управління. На нашу думку, кожне підприємство потребує виваженого аналізу, 3 урахуванням факторів впливу, специфіки організації та продукту, що виробляється.

У процесі створення системи стратегічного управління важливо проводити оцінку iii ефективності з метою пошуку шляхів іiї вдосконалення та розвитку. В даній статті ми проведемо аналіз плану стратегічного розвитку та управління оператора газотранспортної системи України.

Газова промисловість України - це важлива галузь, яка проводить експлуатацію родовищ природного газу, його зберігання, транспортування по газопроводах, забезпечення промисловості та комунального сектору природним газом, займається виробництвом скрапленого газу, переробкою газу та газового конденсату, виробництвом штучних горючих газів з твердого і рідкого палив. Газова промисловість та споживачі формують ринок природного газу. Важливими складовими ринку природного газу є: імпорт газу по трубопровідному транспорту, видобуток, відбір газу експорт, та споживання.

Варто зазначити, що на протязі 2016-2020 років бачимо тенденцію зменшення споживання природного газу в Україні (рис.1)

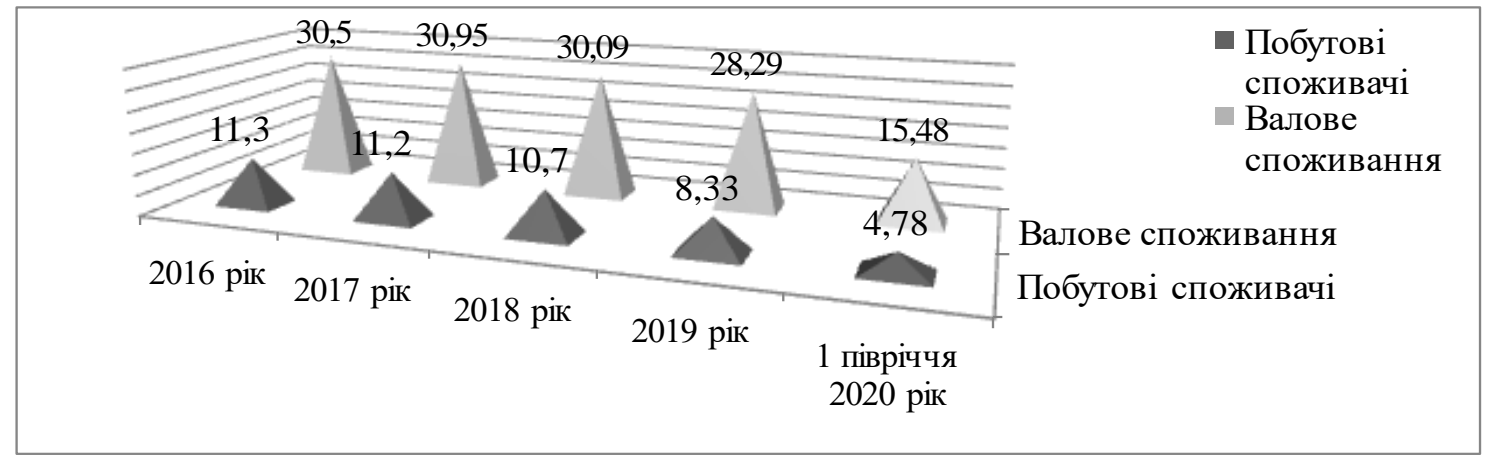

Джерело: згруповано авторами на основі [2] 
Як бачимо з даного рисунку, обсяг валового споживання природного газу показує тенденцію на зниження. Попит на природний газ зменшується також у зв'язку 3 переходом на альтернативні види опалення.

Розвиток ринку альтернативних джерел енергії також безпосередньо впливає на кількість споживання побутового газу (рис.2).

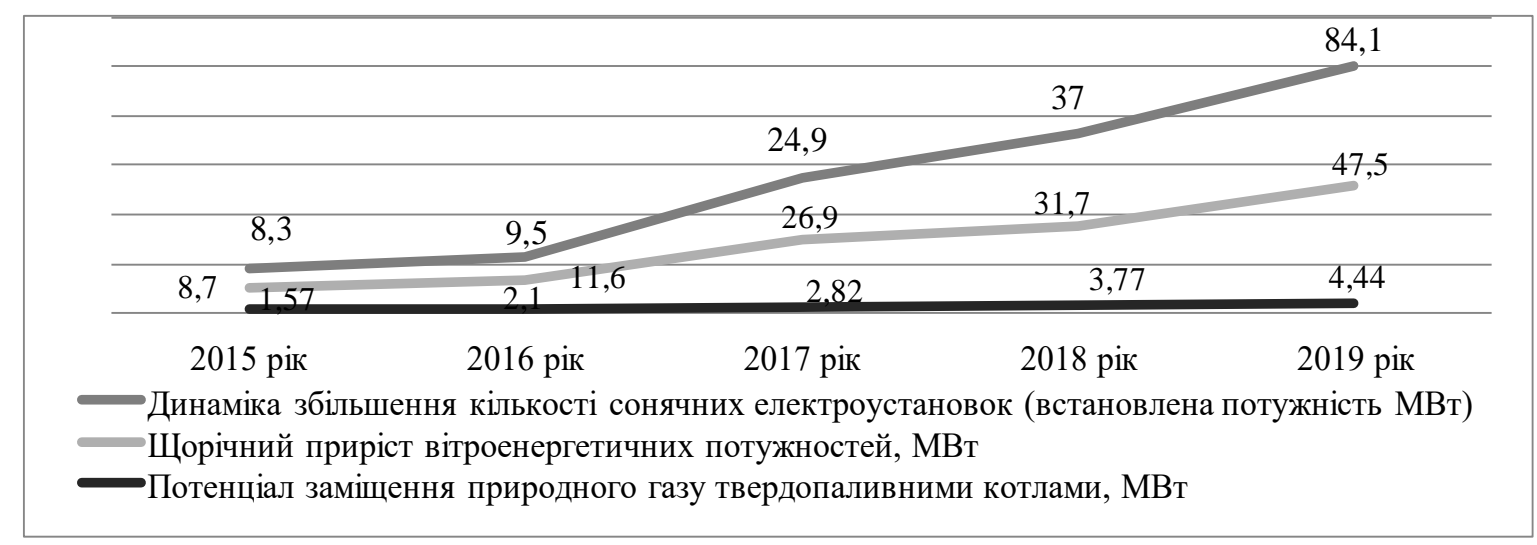

Джерело: згруповано авторами на основі [3,4,5]

Розвиток альтернативних видів палива, програма з енергоефективності призвели до того, що споживання природного газу знизилось більш як на $20 \%$.

З 2019 року, було проведено зміну стратегії розвитку та реформування газотранспортної системи, сформувало основне бачення і вектор розвитку - це інтеграція до європейської газової мережі, як сучасний та інноваційний оператор газотранспортної системи. Крім того, були визначенні основні цінності, а саме: ефективність та надійність, безпека постачання газу, відповідальність та доброчесність у роботі, вплив на ринок.

У таблиці 1 визначено цілі та напрямки стратегічного розвитку газотранспортної системи України у відповідності до діючої стратегії.

Таблиця 1 - Основні цілі розвитку газотранспортної системи України

\begin{tabular}{|c|c|}
\hline Назва цілі & Заходи впровадження цілей \\
\hline 1 & 2 \\
\hline $\begin{array}{c}\text { Ринкова } \\
\text { інтеграція }\end{array}$ & $\begin{array}{l}\text {-перенесення точок приймання російського газу на східний кордон України; } \\
\text {-взаємодія } 3 \text { оператором газосховищ України } 3 \text { метою балансування та } \\
\text { управління ГТС; } \\
\text {-проведення заходів чи робіт направлених на підвищення гнучкості та } \\
\text { надійності роботи ГТС, рівня ії інтегрованості. }\end{array}$ \\
\hline $\begin{array}{c}\text { Сталий } \\
\text { розвиток }\end{array}$ & 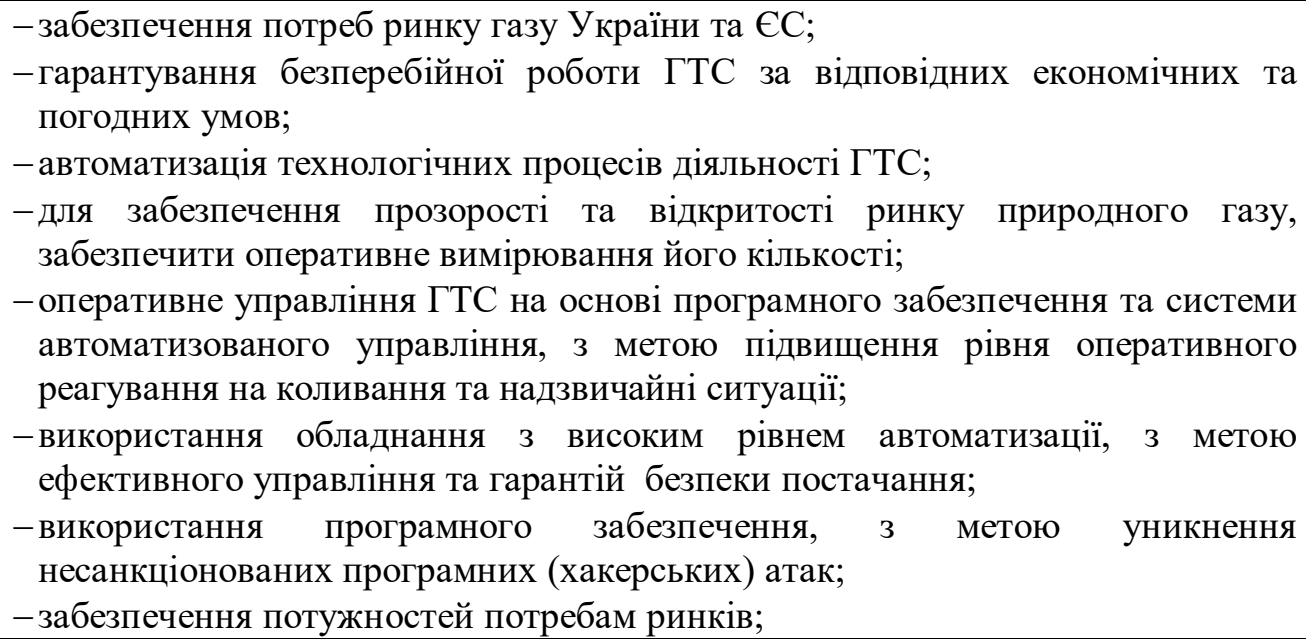 \\
\hline
\end{tabular}


Продовження таблиці1

\begin{tabular}{|c|c|}
\hline 1 & 2 \\
\hline $\begin{array}{l}\text { Сталий } \\
\text { розвиток }\end{array}$ & $\begin{array}{l}\text {-використання обладнання, що гарантує роботу ГТС у відповідності до } \\
\text { передових світових моделей; } \\
\text {-створення системи живлення деяких інфраструктурних об'єктів за рахунок } \\
\text { альтернативних джерел енергії; } \\
\text {-заміна неефективного, застарілого обладнання на сучасне, що відповідає } \\
\text { екологічним вимогам; } \\
\text {-скорочення викидів парникових газів. }\end{array}$ \\
\hline $\begin{array}{l}\text { Ефекти- } \\
\text { вність }\end{array}$ & $\begin{array}{l}\text {-реалізація програми з побудови ефективної ГТС; } \\
\text {-запровадження ІТ-систем з управління потоками газу; } \\
\text {-встановлення сучасного газовимірювального обладнання; } \\
\text {-впровадження заходів, які знижують рівень витрат; }\end{array}$ \\
\hline $\begin{array}{c}\text { Безпека } \\
\text { поставок }\end{array}$ & $\begin{array}{l}\text { - забезпечення газопостачання з Угорщини в Україну; } \\
\text { - транспортування газу через «Транс-Балканський» трубопровід; }\end{array}$ \\
\hline
\end{tabular}

3 таблиці 1 бачимо, що було почало впровадження заходів щодо ринкової інтеграції України до європейської газової спільноти.

Ціль ринкової інтеграції обумовлює широкий спектр розвитку газотранспортної системи. Після проведеного аналізу, ми вважаємо, перенесення точок приймання російського газу на східний кордон України може мати негативні наслідки. У таблиці 2 запропоновано можливість покращення напрямку розвитку підприємства для досягнення ринкової інтеграції.

Таблиця 2 - Альтернатива впровадження заходів ринкової інтеграції

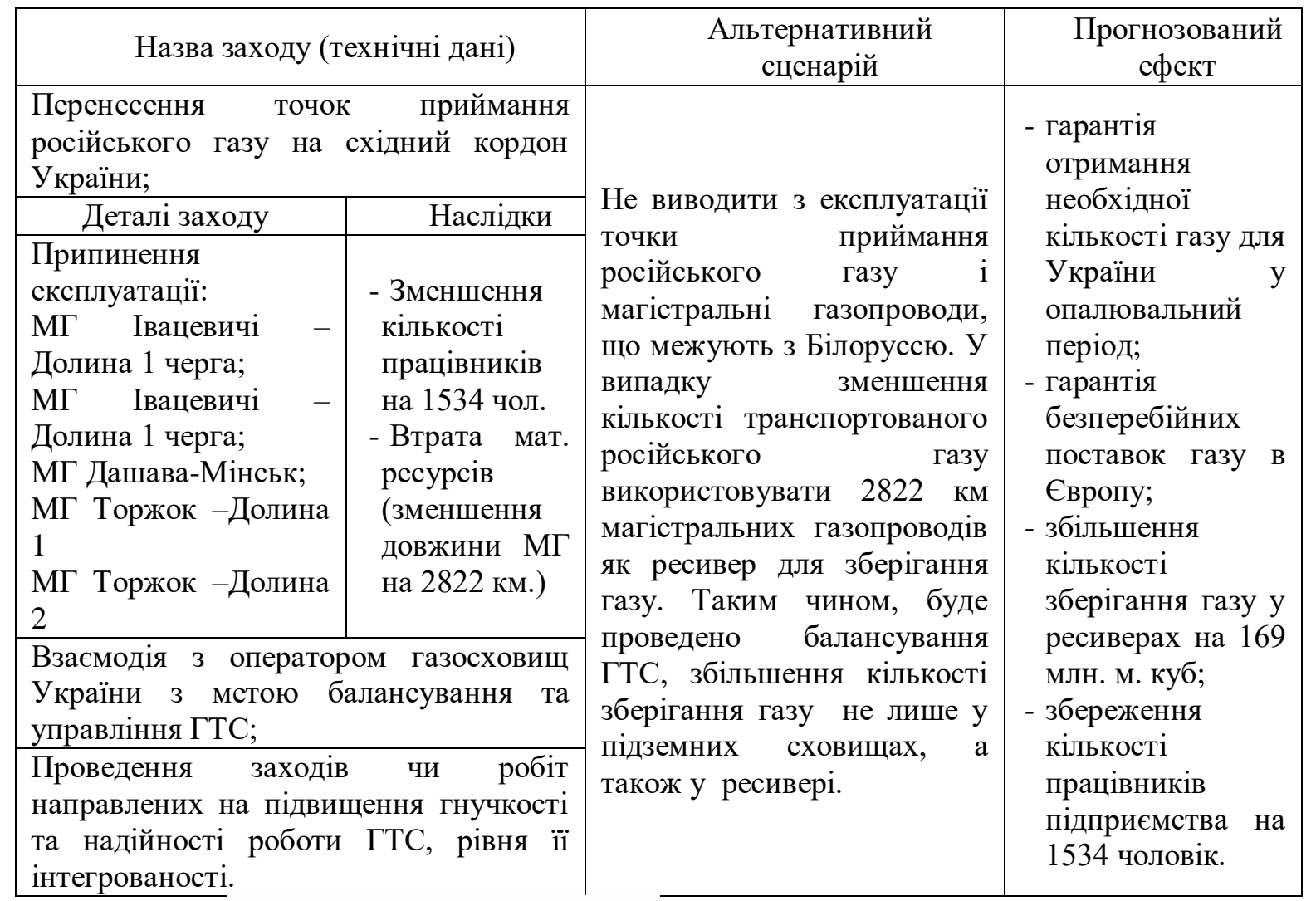

Джерело: згруповано авторами на основі [6] 
У таблиці 2. ми провели аналіз та запропонували альтернативний сценарій впровадження цілей ринкової інтеграції. Замість того, щоб виводити 3 експлуатації магістральні газопроводи, що працюють від точок входу російського газу на територію України, ми пропонуємо їх використовувати, як ресивери. Це дасть можливість зберегти 1534 робочих місця та збільшити кількість зберігання газу на території Україна на 169320 тис. куб. метрів.

Для досягнення цілей, щодо ринкової інтеграції та гарантії безпеки поставок оператор ГТС України планує провести заходи по забезпеченню гарантованих потужностей з Угорщини в Україну. На нашу думку, цей проект пов'язаний з високими ризиками і витратами. Через брак фінансування, українська частина проекту виконана лише на 20\%. Угорська частина проекту також потребує значних матеріальних затрат у вигляді реконструкції компресорних станцій та наземного обладнання магістральних газопроводів.

Станом на 2020 рік роботи по проекту Угорщина не розпочала. Вважаємо, що через високі ризики по введенні в експлуатацію, варто розглянути питання, щодо доцільності проведення робіт по проекту забезпечення гарантованих потужностей 3 Угорщини в Україну.

У плані розвитку газотранспортної системи, були сформовані прогнози споживання природного газу різними категоріями споживачів.

На основі прогнозів були сформовані сценарії і визначена програма стратегічного управління. У таблиці 3. показані фактори впливу на розвиток ГТС кожного сценарію, i визначено найбільш перспективні.

Таблиця 3 - Фактори впливу сценаріїв споживання газу на розвиток ГТУ України

\begin{tabular}{|c|l|}
\hline Сценарій & \multicolumn{1}{|c|}{ Прогнозовані обсяги споживання газу } \\
\hline Національна & $\begin{array}{l}495-505 \text { млрд куб. м на рік. до 2040 року. } \\
\text { скорочення на } 14,0 \%\end{array}$ \\
\hline $\begin{array}{c}\text { тенденція(Блакитний) } \\
\text { генерація(Фіолетовий) }\end{array}$ & $\begin{array}{l}\text { передбачає динамічне скорочення споживання газу. } \\
\text { Скорочення на } 30,8 \%\end{array}$ \\
\hline $\begin{array}{c}\text { Глобальні амбіції } \\
\text { (Зелений) }\end{array}$ & до 393,8 млрд куб. м. до 2040 року, скорочення на $22,0 \%$ \\
\hline Сірий сценарій & до 440,1 млрд куб. м. до 2040 року, скорочення на $13,7 \%$ \\
\hline
\end{tabular}

Джерело: згруповано авторами на основі [6].

Від втілення будь-якого сценарію буде залежати потенціал розвитку підприємства i обрана програма стратегічного управління, і впровадження заходів для досягнення цілей підприємства. Далі, на (рис.3) зображена графічна інтерпретація зменшення обсягів поживання газу, від якого залежить і розвиток аналізованого підприємства.

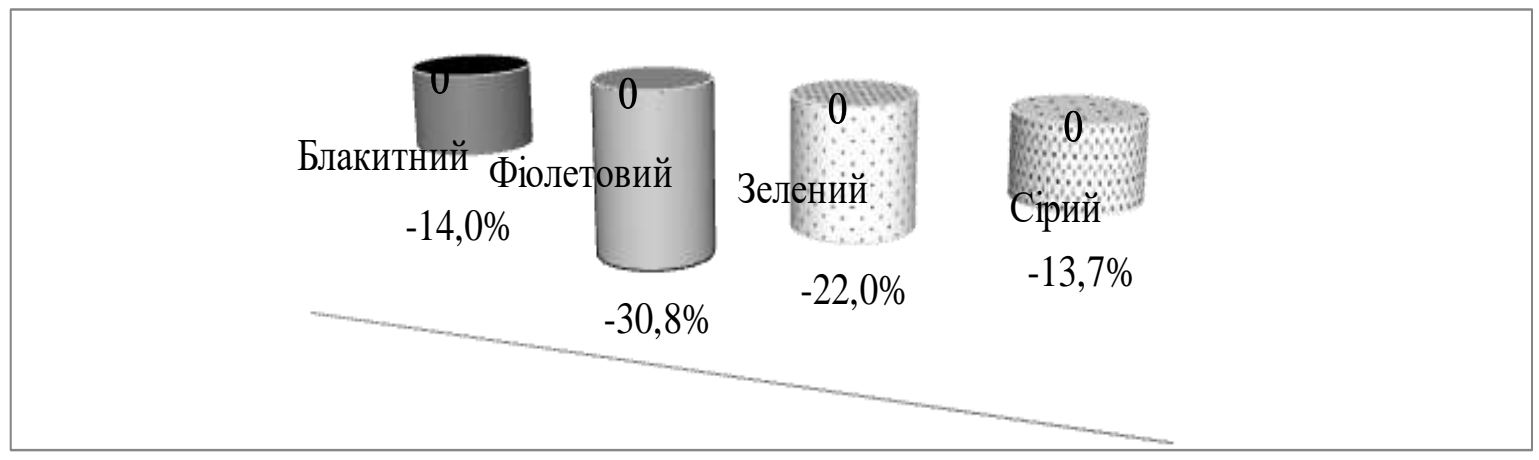

Рис.3. Інтерпретація зменшення споживання газу.

Джерело: згруповано авторами на основі [6] 
Як бачимо з таблиці 3 та рисунку 3 блакитний сценарій для підприємства найбільш прийнятний. Він передбачає пришвидшення темпів економічного зростання. Під час розвитку подій за цим сценарієм передбачається: здійснення контролю за викидами шкідливих речовин, активне використання природного газу в промисловості, модернізацію старих генераційних потужностей, які використовують вугілля на газові установки, прогнозується перехід приватного та громадського транспорту на газ [6].

Після проведення аналізу стратегічного управління газотранспортної системи України можна зробити висновок, що перспективними заходами є: реалізація проекту транспортування природного газу в двох напрямках через ТрансБалканський трубопровід; будівництво магістрального газопроводу-інтерконектора Україна-Румунія. Це співпадає з стратегією оператора ГТС та, в результаті ефективної реалізації, приведе до його до інтеграції в європейську газотранспортну систему.

Українська економіка залежна від імпорту енергоносіїв, важливою складовою якого $є$ російський газ. Його висока ціна $є$ причиною низької конкурентоздатності вітчизняних товарів і конфліктів з Російською Федерацією. У 2019 році в Україні видобуто 20,7 млрд куб. м. газу, а споживання газу - 29,8 млрд куб. м. [7].

Обсяги транспортування газу територією України з Російської Федерації до європейських країн і Молдови становлять 89,6 млрд куб. м. На сьогоднішній день, за наявності політичної та економічної кризи, існує імовірність того, що через українську газотранспортну систему, в перспективі, не буде транспортуватись російський газ. Це може дати негативні наслідки для ГТС та енергетичної безпеки України.

Зважаючи на це, на нашу думку, оператору ГТС України необхідно шукати альтернативні шляхи отримання прибутку, як пропозицію, розглянути можливість транспортування скрапленого газу.

Перспективні запаси сланцевого газу на Олеській та Юзівській газоносних площах в 7 трлн куб. м [8].Схема покладів зображені на (рис 4).
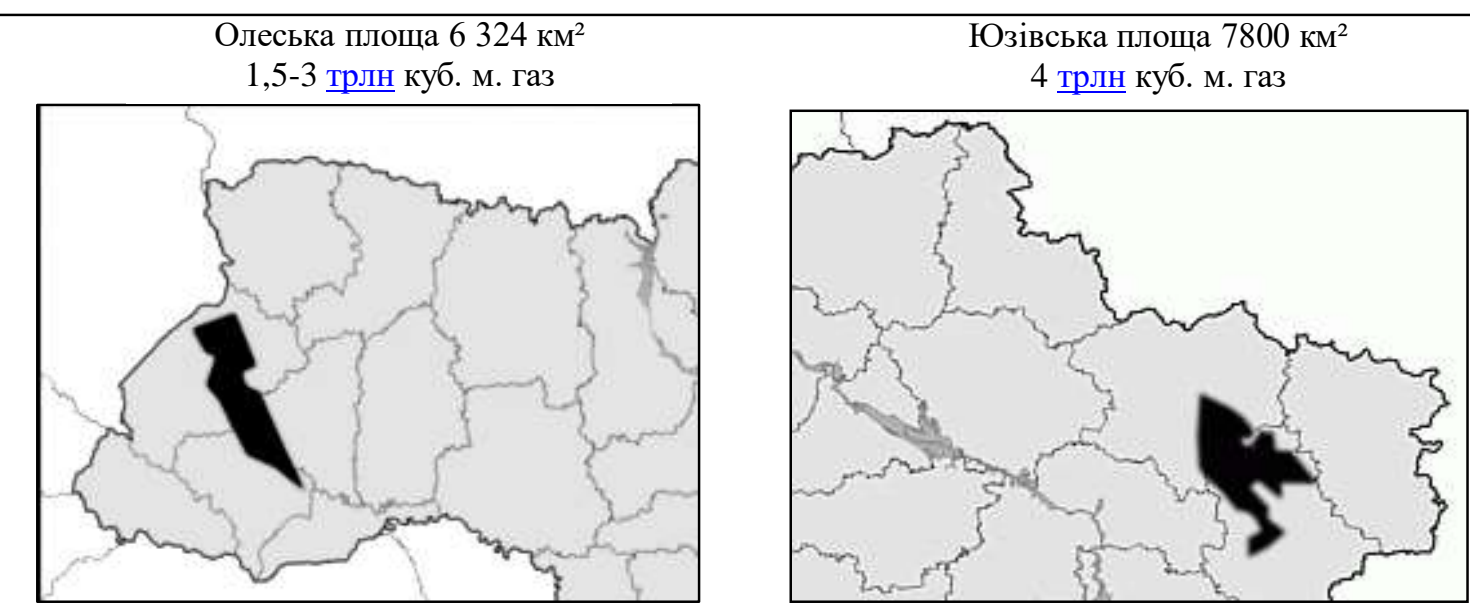

Рис. 4. Розташування Олеської та Юзівської газоносних сховищ.

Джерело: згруповано авторами на основі [8].

Розробка Олеської та Юзівської газоносних сховищ, видобуток та транспортування сланцевого газу може стати перспективною для ГТС України.

Основними етапами впровадження даного проекту та виведення його на промисловий рівень є: проведення геологічної розвідки сховищ, розвідувальне буріння (розвідувальними свердловинами), експлуатаційне буріння, компромування та транспортування газу.

У таблиці 4, ми проведемо аналіз орієнтовної вартості проведення розвідувального буріння Олеської та Юзівської газоносних сховищ. 
Таблиця 4 - Аналіз орієнтовної вартості проведення розвідувального буріння Олеської та Юзівської газоносних сховищ

\begin{tabular}{|c|c|}
\hline Олеська площа: 6324 км² & Юзівська площа: 7800 км² \\
\hline Геологічна розвідка: 8200 тис. грн & Геологічна розвідка: 7235 тис. грн. \\
\hline $\begin{array}{l}\text { Отримання дозволів на } \quad \text { відведення } \\
\text { розробку землі від } 170000 \text { тис. грн. }\end{array}$ & $\begin{array}{l}\text { Отримання дозволів на відведення } \\
\text { розробку землі від } 210000 \text { тис. грн. }\end{array}$ \\
\hline $\begin{array}{lccr}\text { Вартість } & \text { геологічної } & \text { розвідки } & \text { та } \\
\text { розвідувального буріння }-8500 \text { млн. грн. [40] }\end{array}$ & $\begin{array}{l}\text { Вартість геологічної розвідки та буріння - } \\
9150 \text { млн. грн. [40] }\end{array}$ \\
\hline $\begin{array}{l}\text { Орієнтовна } \quad \text { вартість } \\
\text { свердловин може становити } 14875 \text { тис. грн. }\end{array}$ & $\begin{array}{l}\text { Орієнтовна вартість } \\
\text { свердловин мозвідувальних } \\
\text { можановити } 20748 \text { тис. грн. }\end{array}$ \\
\hline $\begin{array}{l}\text { Процес сепарації газу, осушення газу. } 1200 \\
\text { тис. грн.- на одну свердловину. Разом на } 85 \\
\text { свердловини - } 102000 \text { тис. грн. }\end{array}$ & $\begin{array}{l}\text { Процес сепарації газу, осушення газу. } 1200 \\
\text { тис. грн.- на одну свердловину. Разом на } 104 \\
\text { свердловини - } 124800 \text { тис. грн. }\end{array}$ \\
\hline $\begin{array}{l}\text { Аналізу газ - } 2430 \text { грн. } 3 \text { однієї свердловини. } \\
\text { Разом на } 85 \text { свердловини - } 207 \text { тис. грн. }\end{array}$ & $\begin{array}{l}\text { Аналіз газу - } 2430 \text { грн. } 3 \text { однієї свердловини. } \\
\text { Разом на } 104 \text { свердловини - } 253 \text { тис. грн. }\end{array}$ \\
\hline $\begin{array}{l}\text { Орієнтовні витрати для проведення } \\
\text { геологічної розвідки Юзівського газоносного } \\
\text { сховища } 8795 \text { млн. грн }\end{array}$ & $\begin{array}{lcc}\text { Орієнтовні } & \text { витрати для } & \text { проведення } \\
\text { геологічної } & \text { розвідки } & \text { Юзівського } \\
\text { газоносного сховища } 9324 \text { млн. грн }\end{array}$ \\
\hline \multicolumn{2}{|c|}{ Разом: 18119 млн. грн. } \\
\hline
\end{tabular}

Після проведення розрахунків, на первинний етап розробки Олеської та Юзівської газосховищ для видобутку сланцевого газу необхідно витратити 18119 млн. грн.

У таблиці 5, ми проведемо аналіз орієнтовної вартості робіт, починаючи від процесу експлуатаційного буріння в газоносних сховищ до потрапляння готової продукції до газокомпресорної станції.

Таблиця 5 - Аналіз орієнтовної вартості робіт видобутку скрапленого газу

\begin{tabular}{|l|c|}
\hline \multicolumn{1}{|c|}{ Характеристика та вид робіт, що плануються проводитись } & $\begin{array}{c}\text { Орієнтовна } \\
\text { вартість робіт }\end{array}$ \\
\hline $\begin{array}{l}\text { Будівництво 3000 експлуатаційних свердловин кожна з яких може давати } \\
\text { до 10 тис. куб. м газу за добу та 500 колодязів для них. }\end{array}$ & 75570 млн. грн. \\
\hline Вартість спеціального дозволу на користування надрами & 120 млн грн. \\
\hline Проведення 3D-сейсміки на Олеській та Юзівській газоносних сховищ & 60 млн грн. \\
\hline На будівництво майданчика для буріння на ділянці газоносних сховищ & 250 млн. грн. \\
\hline Будівництво інфраструктури з транспортування та підготовки газу & 400 млн грн. \\
\hline $\begin{array}{l}\text { Будівництво шельфу, процес очищення, відокремлення газу від води } \\
\text { (осушення газу) за допомогою реагентів, очищення технічної води. }\end{array}$ & 2000 млн. грн. \\
\hline $\begin{array}{l}\text { Орієнтовна вартість угоди на будівництво інфраструктури буріння, } \\
\text { проведення пуско-налагоджувальних робіт }\end{array}$ & 42750 млн. грн. \\
\hline Разом: & 121050 млн. грн. \\
\hline
\end{tabular}

Джерело: згруповано авторами на основі $\overline{[9,10]}$

3 таблиці 5, бачимо, на експлуатаційний етап розробки Олеської та Юзівської газосховищ для видобутку сланцевого газу необхідно витратити 121050 млн. грн. При будівництві 3000 експлуатаційних свердловин, при розрахунку 10 тис. куб. м газу за добу від однієї свердловини, вони в сумі можуть дати 10,9 млрд. куб. м газу в рік.

При загальному використанні природного газу за рік у кількості 29,8 млрд куб. м., власному видобутку 20,7 млрд куб. м. і видобутку сланцевого газу за прогнозом, проведеним у таблиці 5, Україна зможе досягнути енергетичної незалежності i відмовитись від імпорту газу. Загальна вартість реалізації проекту по видобутку сланцевого газу може становити 139169 млн. грн. Собівартість транспортування 10,9 
млрд. куб. м газу в рік магістральними газопроводами, при ціні 193,8 грн. за 1000 куб. м. буде становити 21124 млн. грн.

Таким чином, оператор ГТС України, при реалізації проекту з видобутку сланцевого газу, при проведенні робіт екологічної, геологічної розвідки перспективних газоносних сховищ, розвідувального та експлуатаційного буріння, через 10-15 років може отримати альтернативний вид доходу у сумі 101893 млн. грн. за рік (при об'ємі видобутку 10,9 млрд. куб. м газу в рік; вартості газу - 7410 грн. за тис. куб. м газу; при ціні транспортування 193,8 грн. за 1000 куб. м.)

Висновки. Ефективна система стратегічного управління, це впровадження перспективних заходів для досягнення цілей організації, постійний моніторинг факторів, що можуть впливати на іiі розвиток. Аналіз середовища дає розуміння ймовірних можливостей і загроз, що стоять перед підприємством. Крім того, дає розуміння, які сильні сторони є рушійними силами для конкурентної боротьби та які внутрішні слабкі сторони викликають проблеми, пов'язані з зовнішніми небезпеками. Пошук перспектив розвитку може стати запорукою економічного зростання.

\section{Список бібліографічного опису:}

1.Стратегічне управління Шершньова 3. С. Підручник. 2-ге вид., перероб. і доп. К.: КНЕУ, 2004. 699 с.

2.Національна комісія, що здійснює державне регулювання сферах енергетики та комунальних послуг /Результати моніторингу функціонування ринку природного газу. URL:

http://www.nerc.gov.ua/data/filearch/monitoryng/gas/2020/monitoryng_gaz_I-2020.pdf

3.Біоенергетична асоціація України URL: https://bio.ukr.bio/ua/articles/9784/

4.Вітроенергетика України URL: http://uwea.com.ua/uploads/docs/uwea_2018_ua_web.pdf

5.Публічний звіт Голови Держенергоефективності Розвиток сфери енергоефективності та «зеленої» енергетики в Україні URL: http://saee.gov.ua/sites/default/files/2018_19_report_07_02_2019.pdf

6.План розвитку газотранспортної системи, Затверджено постановою НКРЕКП від 17.13.2020 року № 619.148 с.

7.У 2019 рокі видобуток газу в Україні зменшився на 1,4\%. Офіційний сайт НАК «Нафтогаз України» URL:https://tsoua.com/pro-nas/misia-bachennya-tsinnosti/

8.Україна може досягти газової незалежності протягом десяти років/ ДЕРЖАВНА СЛУЖБА ГЕОЛОГІї ТА НАДР УКРАЇ̈И/ URL: https://www.geo.gov.ua/?s=сланцевий+газ\&lang=uk

9.Сланцевий газ: і можна, і треба/ Василь Суярко, доктор - геолого-мінералогічних наук, професор, академік Української нафтогазової академії / Економічна правда від 06.02.2013 poкy/ URL: https://www.epravda.com.ua/columns/2013/02/6/360309/

10. Собівартість видобутку в Україні сланцевого газу буде набагато вищою, ніж у США/ заступник директора Центру економічного розвитку при коледжі урбаністики Державного університету Клівленда, доктор Ірина Лендел./Радіо Свобода від 07.10.2013 року URL: /https://www.radiosvoboda.org/a/25129418.html

\section{References:}

1. Strategic Management Shershneva ZE Textbook. 2nd ed., Revised. and ext. K .: KNEU, 2004. 699 s. [in Ukrainian]

2. National Commission for State Regulation of Energy and Utilities / Results of monitoring the functioning of the natural gas market. URL:

http://www.nerc.gov.ua/data/filearch/monitoryng/gas/2020/monitoryng_gaz_I-2020.pdf [in Ukrainian]

3. Bioenergy Association of Ukraine URL: https://bio.ukr.bio/ua/articles/9784/ [in Ukrainian]

4. Wind energy of Ukraine URL: http://uwea.com.ua/uploads/docs/uwea_2018_ua_web.pdf [in Ukrainian]

5. Public report of the Head of the State Agency for Energy Efficiency Development of energy efficiency and "green" energy in Ukraine URL: http://saee.gov.ua/sites/default/files/2018_19_report_07_02_2019.pdf [in Ukrainian]

6. Gas transmission system development plan, Approved by the resolution of the National Commission for Regulation of Economic Competition dated 17.13.2020 3. 619. 148 p. [in Ukrainian]

7. In 2019, gas production in Ukraine decreased by $1.4 \%$. Official website of Naftogaz of Ukraine URL: https: //tsoua.com/pronas/misia-bachennya-tsinnosti/ [in Ukrainian]

8. Ukraine can achieve gas independence within ten years / STATE SERVICE OF GEOLOGY AND SUBSTANCES OF UKRAINE / URL: https://www.geo.gov.ua/?s=slate+gas\&lang=en[in Ukrainian]

9. Shale gas: both possible and necessary / Vasyl Suyarko, Doctor - Geological and Mineralogical Sciences, Professor, Academician of the Ukrainian Oil and Gas Academy / Economic Truth from 06.02.2013 / URL: https://www. althoughda.com.ua/ columns / 2013/02/6/360309 / [in Ukrainian]

10. The cost of shale gas production in Ukraine will be much higher than in the US / Deputy Director of the Center for Economic Development at the College of Urbanism of the State University of Cleveland, Dr. Irina Lendel./Radio Svoboda from 07.10.2013 URL: /https://www.radiosvoboda .org / a / 25129418.html [in Ukrainian]

Дата подання публікації 03.12.2020 p. 